\title{
LOS TRIBUNALES PENALES INTERNACIONALES \\ COMO ANTECEDENTES DE LA APLICACIÓN DEL \\ DERECHO INTERNACIONAL A LOS INDIVIDUOS
}

\author{
INTERNATIONAL CRIMINAL COURTS AS A BACKGROUND TO THE APPLICATION \\ OF INTERNATIONAL LAW TO INDIVIDUALS
}

\section{OS TRIBUNAIS PENAIS INTERNACIONAIS COMO ANTECEDENTES DA APLICAÇÃO DO DIREITO INTERNACIONAL AOS INDIVIIDUOS}

\section{Oscar Orlando Casallas Méndez ${ }^{1}$}

\section{Nicolás Carrillo Santarelli²}

Licença CC BY:

Artigo distribuído sob os termos Creative Commons, permite uso e distribuição irrestrita em qualquer meio desde que $o$ autor credite a fonte original.

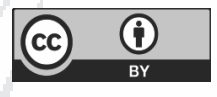

\begin{abstract}
Resumen: El propósito general del artículo es analizar los antecedentes de la aplicación del derecho internacional a los individuos, teniendo como punto de partida los tribunales penales internacionales. Del mismo modo, esta investigación también aborda los criterios que permitieron el juzgamiento de individuos frente a estos tribunales. Por lo tanto, se estudiará em el primer momento los juicios de los Tribunales Militares Internacionales de Núremberg, el cual, a partir de su entrada en funcionamiento, asumió la responsabilidad de juzgar a los individuos señalados por cometer crímenes de guerra, contra la humanidad y la paz durante la Segunda Guerra Mundial. El segundo de los antecedes que se analizará, es la constitución de los Tribunales ad hoc de Yugoslavia (TPIY) y Ruanda (TPIR), los cuales fueron creados como respuesta por parte de la comunidad internacional con la finalidad exclusiva de enjuiciar algunos de los crímenes más graves cometidos a finales del siglo XX. Finalmente, se analiza la Corte Penal Internacional $(\mathrm{CPI})$, que juzga los crímenes internacionales más graves dentro de los escenarios específicos, y los tribunales mixtos. En las distintas fases de la Investigación, se aplicaron las técnicas de referencia, categoría, concepto operativo e investigación bibliográfica. En cuanto a la metodología utilizada, se registra que, en la fase de investigación, se utilizó el método inductivo, en la fase de procesamiento de datos, el método cartesiano, y los resultados expresados con base lógica inductiva.
\end{abstract}

\footnotetext{
$1 \quad$ Magister en Derecho Internacional de la Universidad de la Sabana, abogado de la Universidad Nacional de Colombia y actualmente cursando la Maestría en Análisis de Problemas Políticos, Económicos e Internacionales. Miembro de la Academia Colombiana de Derecho Internacional (ACCOLDI) e investigador y autor en obras conjuntas y artículos académicos en Derecho Internacional. Diplomático de carrera y profesor de cátedra de Derecho Internacional. Colombia. Correo electrónico: oocasallasm@unal.edu.co

2 Profesor de Derecho Internacional de la Universidad de La Sabana, Colombia. Doctor en Derecho Internacional y Relaciones Internacionales por la Universidad Autónoma de Madrid, y Diploma de Estudios Avanzados en Derecho Internacional y Relaciones Internacionales de la misma Universidad; maestría en Protección de los Derechos Humanos de la Universidad de Alcalá, y licenciado en Derecho de la Universidad Externado de Colombia. Abogado egresado de la Pontificia Universidad Javeriana. Correo electrónico: nicolas.carrillos@gmail.com
} 
Palabras clave: Tribunal Penal Internacional; Derecho Internacional; Individuos.

Abstract: The general purpose of the article is to analyse the background to the application of international law to individuals, with the starting point for international criminal courts. Similarly, this investigation also addresses the criteria that allowed the judgement of individuals in front of these courts. Therefore, it will be studied in the first moment the trials of the Nuremberg International Military Courts, which, from his entry into function, had a responsibility to try the individuals reported to commit war crimes, against humanity and peace during World War II. The second of the antecedents to be analysed is the establishment of the Ad Hoc Courts of Yugoslavia (ICTY) and Rwanda (TPIR), which were created in response by the international community to some of the most serious crimes committed at the end of the twentieth century. Finally, the International Criminal Court (ICC) is analysed, which judges the most serious international crimes within specific scenarios, and mixed courts. In the different phases of the Research, the Reference Techniques, category, operational concept and bibliographic research were activated. Regarding the methodology used, it is recorded that, in the Research Phase, the Inductive Method was used, in the Data Processing Phase the Cartesian Method, and the Results expressed on an inductive logical basis.

Keywords: International criminal court; International Law; Individuals.

Resumo: O propósito geral deste artigo é analisar os antecedentes da aplicação do direito internacional aos indivíduos, tendo como ponto de partida os Tribunais Penais Internacionais. De igual modo, esta pesquisa também aborda os critérios que permitem o julgamento de indivíduos frente a estes tribunais. Assim, serão estudados em primeira instância os julgamentos dos tribunais militares internacionais de Nuremberg, que, a partir de seu funcionamento, assumiu a responsabilidade de julgar os indivíduos acusados de cometer crimes de guerra contra a humanidade e a paz durante a Segunda Guerra Mundial. O segundo antecedente analisado é a constituição dos tribunais ad hoc de Jugoslávia (TPIJ) e Ruanda (TPIR), criados como uma resposta da comunidade internacional com o propósito exclusivo de julgar alguns dos delitos mais graves cometidos no final do século XX. Finalmente, é analisada a Corte Penal Internacional (CPI), que julga os delitos internacionais mais graves em contextos específicos e os tribunais mistos. Nas diferentes fases da pesquisa, foram aplicadas as técnicas de referência, categorização, conceito operativo e pesquisa bibliográfica. Quanto à metodologia utilizada, registra-se que, na fase de pesquisa, foi utilizado o método indutivo; na fase de processamento de dados, foi utilizado o método cartesiano e a base lógica indutiva para os resultados expressados.

Palavras chaves: Tribunal Penal Internacional; Direito Internacional. Indivíduos.

\section{INTRODUCCIÓN}

La creación de los tribunales penales internacionales para enfrentar situaciones particulares que han puesto en riesgo la paz y seguridad no es algo nuevo. De hecho, a través del DIP, obligaciones generales del DI dirigidas en principio a los Estados, se han tornado vinculantes para los individuos como consecuencia de las condenas que se dictaminaron por distintos tribunales internacionales, y precisamente, estos antecedentes serán los que se procederán a analizar.

Podemos realizar una comparación entre el peligro para la paz y seguridad internacional que representa el terrorismo internacional con otros eventos que en décadas pasadas han producido 
cambios significativos en el DI. Por ejemplo, al final de la Segunda Guerra Mundial fueron creados los Tribunales Militares Internacionales de Núremberg y Tokio (TMI), el conflicto en los Balcanes y en el genocidio de Ruanda, tendrían como consecuencia la creación por parte del CSNU, los Tribunales Ad hoc sobre crímenes cometidos en la ex República de Yugoslavia (TIPY) y el Tribunal Penal Internacional para Ruanda (TPIR). En casos más recientes, se tiene la Corte Penal Internacional (CPI) y los Tribunales Especiales para Sierra Leona y el Líbano, los cuales fueron producto de necesidades puntuales que justificaron su creación con base en un sistema colaborativo entre los Estados y el CSNU. La atribución de responsabilidad criminal por los actos más atroces ha representado un ejercicio sin paralelo que posibilito la ejecución (enforcement) del DI. Por lo tanto, la efectividad del DI se refleja en el juzgamiento de delitos que han sido las ofensas más graves acontecidas en el mundo, con miles de víctimas que ocurrieron (en su mayoría) dentro de conflictos armados internacionales y en contextos donde el sistema judicial de los Estados había desaparecido. ${ }^{3}$ Esto significa que el DI no ha permanecido estático a la introducción de nuevas obligaciones internacionales, sino que por el contrario se vuelve aplicable a través del DPI, siendo así, la judicialización de individuos por crímenes internacionales es una característica del DI cada vez más presente y también de las más visibles.

Por lo tanto, en esta investigación se estudiará los criterios que permitieron el juzgamiento de individuos frente a tribunales internacionales, en cuatro grandes hitos, que son: 1) Los Tribunales Militares Internacionales (TMI) de Núremberg, 2) Los Tribunales Ad hoc de Ruanda y Yugoslavia (TPIY, TPIR), 3) La Corte Penal Internacional (CPI) y 4) Los Tribunales Especiales. Si bien en su momento, no parecía probable y resultaba muy discutible que los responsables de crímenes fueran juzgados en el plano internacional, gracias al desarrollo de nuevas obligaciones internacionales.

\section{JUICIOS DE LOS TRIBUNALES MILITARES INTERNACIONALES DE NÚREMBERG}

El primer antecedente es el Tribunal Militar Internacional de Núremberg (TMI). ${ }^{4}$ ). El cual, a partir de su entrada en funcionamiento en el año 1945, asumió la responsabilidad de juzgar a los individuos señalados por cometer crímenes de guerra, contra la humanidad y la paz durante la Segunda Guerra Mundial. Lo que generó cambios fundamentales en la concepción del sistema internacional, tales como el que impone el Dl, deberes y responsabilidades a los individuos de manera similar que los Estados y la supremacía del DI frene el derecho interno. ${ }^{5}$ Adicionalmente, por primera vez en

$3 \quad$ RALSTON, John; FINNIN, Sarah. Investigating International Crimes: A Review of International Law Enforcement Strategies Blumenthal. in David. \& McCormack, Timothy L.H. The Legacy of Nuremberg: Civilizing Influence or Institutionalized Vengeance?, Leiden: Martinus Nijhoff Publishers, 2008, p. 48.

$4 \quad$ Los TMI se desarrollaron el dos necesarios, el europeo con los juicios de Núremberg y el asiático con los Tribunales de Tokio. Para efectos metodológicos y por proximidad son los sistemas jurídicos se analizará únicamente los juicios llevados en Núremberg por parte de las naciones aliadas en contra de los criminales de guerra de Alemania.

5 TMI. The Trial of German Major War Criminals: Before the International Military Tribunal. Vol. 1. Germany. 1947. Disponible en https://www. loc.gov/rr/frd/Military_Law/pdf/NT_Vol-I.pdf; ver también: ILC. Principles of international law recognized in Charter of Nierenberg Tribunal and in the judgment tribunal, Yearbook of the International Law Commission. vol. II. 1950. Disponible en: http://legal.un.org/ilc/texts/ instruments/english/commentaries/7_1_1950.pdf 
la historia, líderes de Estados fueron procesados por un tribunal penal internacional, que, si bien presentó bastantes inconvenientes desde su creación, resultó ser una parte fundacional del DPI, y algunos autores consideran, que desde este momento el DI se vio fortalecido (enforcement) y ejecutable frente a sujetos particulares. ${ }^{6}$

Una vez terminada la Segunda Guerra Mundial, las naciones que resultaron vencedoras se encontraron con el dilema de ¿Qué hacer con los responsables y criminales de guerra? Frente a lo cual surgieron varias propuestas, la propuesta del gobierno británico, era evadir cualquier tipo de juicio y condenar a los máximos líderes del nazismo a un pelotón de fusilamiento. Lo cual era una política desde 1943, porque se pensaba que otorgarles a los líderes nazis la oportunidad de un juicio, esta sería utilizada como un punto de unión para el nacionalismo alemán y británico. ${ }^{7}$ Por su parte, los juristas de la Soviéticos insistían en la necesidad de juicios públicos, a través de los cuales se impusieran a los líderes de la Alemania nazi, penas ejemplarizantes (que en la mayoría de los casos era la pena de muerte), ya que, en su experiencia en un juicio público era posible exponer los crímenes cometidos, legitimando así la sentencia en contra de los acusados. ${ }^{8}$

No está por demás decir que las posiciones asumidas por británicos y soviéticos frente a qué hacer con los criminales de guerra alemanes después del final de la Segunda Guerra Mundial, se dieron en un contexto previo a la creación de la Organización de las Naciones Unidas, y del desarrollo de normas de Derechos Humanos (D.D.H.H.), por lo que las posturas además de ser muy políticas fueron muy radicales. Y una vez se realizó la primera conferencia de la ONU en la ciudad de San Francisco en mayo de 1945, se llegó a un acuerdo entre las potencias vencedoras, y se determinó que los líderes del Eje debían ser juzgados por un Tribunal Militar, compuesto por Estados Unidos, Francia e Inglaterra. ${ }^{9}$ De acuerdo con Philip Sands, la tarea de estructurar un tribunal de esta naturaleza era totalmente novedoso para su época, y la responsabilidad de coordinar a los Estados para el diseño del TMI cayó en las manos del abogado norteamericano Robert H. Jackson - chief proesecutor, quien de acuerdo con varios autores fue una de las principales figuras en los juicios de Núremberg. ${ }^{10}$

Desde un principio, la creación y el funcionamiento del TMI enfrentó muchas dificultades. Sólo basta con mencionar la inexistencia de antecedentes de este tipo de acciones y las tensiones políticas que durante este período existían entre las potencias vencedoras, lo que pudo ser suficiente para que el proyecto del TMI llegara a su final. ${ }^{11}$ Pero desde un punto de vista jurídico resultó bastante difícil

6 OVERY, Richard, The Nuremberg trials: international law in the making. in SANDS, Philippe. From Nuremberg to The Hague. Cambridge: University Press, 2003, p. 9.

7 OVERY, Richard, The Nuremberg trials: international law in the making. in SANDS, Philippe. From Nuremberg to The Hague, p. 3

8 OVERY, Richard, The Nuremberg trials: international law in the making. in SANDS, Philippe. From Nuremberg to The Hague, p. 5.

9 BLEWITT, Graham. The Importance of a Retributive Approach in SANDS, Philippe. From Nuremberg to The Hague. Cambridge: University Press, 2003, p. 40.

10 "Jackson was the principal architect of the trial and the decisive figure in holding together an unhappy alliance of Soviet, British and French jurists, who represented the only other United Nations states to be allowed to participate in the tribunal" OVERY, Richard, The Nuremberg trials: international law in the making. in SANDS, Philippe. From Nuremberg to The Hague, p. 5.

11 En 1945 era evidente el inicio del conflicto entre la URSS y E.E.U.U, lo que hacía difícil cualquier tipo de comparación entre estos dos Estados. 
conciliar los sistemas legales de los Estados que conformaban el TMI. Por su parte, si bien la posición de los soviéticos propugnaba por un juicio, ellos no se encontraban particularmente interesados en el debido proceso, sino simplemente en llegar a un resultado de condena, mientras que los abogados franceses criticaban que el TMI se fundamentara el sistema penal anglosajón (common law) en vez del sistema romano o continental, ya que el common law resultaba muy extraño para los juristas franceses. $^{12}$

Pero más allá de los problemas políticos y de la elección del sistema jurídico o de las convicciones políticas para el juzgamiento de los jerarcas nazis, cuando estas barreras surtieron efecto, los TMI y los Estados se encontraron con uno de los retos más grandes, el cual era decidir los delitos (crímenes) por los cuales debían ser juzgados los acusados ante el Tribunal. Y sobre este aspecto es necesario reiterar, que hasta 1945 la idea de que un órgano judicial internacional juzgara a individuos (y no a Estados) por crímenes internacionales era completamente nueva.

Después de varias discusiones, los cargos formulados en contra de los acusados se centraron en cuatro grandes delitos, que eran: I) conspiración para hacer la guerra agresiva, II) crímenes contra la paz, III) crímenes de guerra; y IV) crímenes contra la humanidad. ${ }^{13}$ Los cuales nunca habían sido establecidos como delitos, es decir, en su mayoría no existían fuentes de derecho que tipificaran las mencionadas conductas como crímenes internacionales en el momento en que fueron cometidos, y solo con excepción de los crímenes de guerra, era posible argumentar la existencia de obligaciones internacionales anteriores. ${ }^{14}$ Pero incluso este último no se encontraba definido expresamente como un crimen internacional, de manera que las actuaciones del Tribunal podrían representar una violación directa al principio de nulle crime sine lege, ante el vacío normativo por las conductas que pretendían imputar.

Inclusive con la variedad de Estados involucrados en la preparación de los TMI, para la mayoría de ellos resultaba extraña la aplicación retrospectiva de delitos. ${ }^{15}$ Aunque en lo que respecta a los crímenes de guerra el TMI argumentó que este los había aceptado previamente como delitos internacionales, a través de la costumbre y con la adopción de la Primera Convención de Ginebra de 1864 y las dos Conferencia de la Haya de 1899 y $1907 .{ }^{16}$ Sin embargo, frente a los crímenes contra la

12 OVERY, Richard, The Nuremberg trials: international law in the making. in SANDS, Philippe. From Nuremberg to The Hague, p. 6.

13 KELLY, Michael J; MCCORMAC, Timothy. Contributions of the Nuremberg Trial to the Subsequent Development of International Law. in The Legacy of Nuremberg: Civilizing Influence or Institutionalized Vengeance? Leiden: Martinus Nijhoff Publishers, 2008, p. 105; Ver también: BLEWITT, Graham. The Importance of a Retributive Approach. in SANDS, Philippe. From Nuremberg to The Hague. 2003.

14 "The crimes of which the defendants stood accused were not regarded as crimes when they were committed, with the exception of war crimes as defined under international agreement." OVERY, Richard, The Nuremberg trials: international law in the making. in SANDS, Philippe. From Nuremberg to The Hague, p. 21.

15 KELLY, Michael J; MCCORMAC, Timothy. Contributions of the Nuremberg Trial to the Subsequent Development of International Law. in The Legacy of Nuremberg: Civilizing Influence or Institutionalized Vengeance? p. 105; OVERY, Richard, The Nuremberg trials: international law in the making. in SANDS, Philippe. From Nuremberg to The Hague. p. 22

16 OVERY, Richard, The Nuremberg trials: international law in the making. in SANDS, Philippe. From Nuremberg to The Hague. Teniendo en cuenta que la Convención de Ginebra para Mejoramiento de las Condiciones de los Heridos en los Ejércitos en el Campo, entró en vigor el 22 de junio de 1865. 
humanidad y la paz, no había ninguna norma de DI destinada a enmarcar las acusaciones respecto a los actos de preparación, iniciación y/o conducción de la guerra agresiva o inclusive de los crímenes en contra de la humanidad. De manera que la defensa argumentó enérgicamente en contra de la penalización, ya que la regulación de dichos crímenes de manera posterior era una violación al principio de nullem crimen sine lege. ${ }^{17}$

Para Sands el propósito central del TMI no era confirmar la existencia de principios en DI, sino establecer nuevas reglas de conducta internacional frente a las violaciones de derechos humanos. ${ }^{18}$ $Y$ es bajo este razonamiento que podemos entender, que en su momento Robert Jackson fiscal del tribunal, consideró que los actos que serían juzgados han sido considerados como crímenes desde el momento de Caín, ${ }^{19}$ refiriéndose a la evidente ilegalidad de los actos cometidos por los alemanes durante la guerra, y pasando por alto el principio de nulle crime sine lege. Si bien, este parece un argumento un poco simple para otorgarle validez a los TMI, posteriormente fue expuesto de una manera más estructurada dentro del desarrollo de los juicios, en palabras del jurista norteamericano Robert Jackson:

The wrongs which we seek to condemn and punish have been so calculated, so malignant, and so devastating, that civilization cannot tolerate their being ignored, because it cannot survive their being repeated. That four great nations, flushed with victory and stung with injury stay the hand of vengeance and voluntarily submit their captive enemies to the judgment of the law is one of the most significant tributes that Power has ever paid to Reason. ${ }^{20}$

Aun así, la aplicación de la justicia retributiva en los TMI no fue absoluta, durante la redacción de los estatutos del TMI, se planteó la posibilidad de juzgar los crímenes contra la humanidad cometidos antes del inicio de la Segunda Guerra Mundial en 1939. Motivo por el cual, para minimizar los efectos de la justicia retrospectiva, se consideró que era necesario restringir los crímenes contra la humanidad en el contexto del conflicto armando internacional. ${ }^{21}$ En opinión del TMI, no podría hacer declaración alguna por los hechos cometidos antes del conflicto armando sin importar lo graves que fueran ya que no existía conexión directa. ${ }^{22}$ Esto a la postre sería una espada de doble

17 ZOLLER, Elizabeth. The Status of Individuals under International Law. in GINSBURGS, George; KURIADTSEV, V.N., The Nuremberg Trial and International Law. Dordrecht: Martinus Nijhoff Publishers, 1990, p. 101; KELLY, Michael J; MCCORMAC, Timothy. Contributions of the Nuremberg Trial to the Subsequent Development of International Law. in The Legacy of Nuremberg: Civilizing Influence or Institutionalized Vengeance? p. 106.

18 "The central purpose of the Tribunal was not to conform to existing principles in international law but to establish new rules of international conduct and agreed boundaries in the violation of human rights. SANDS, Philippe. From Nuremberg to The Hague. p. 23.

19 SANDS, Philippe. From Nuremberg to The Hague. p. 23.

20 TMI. United States et al v Hermann Wilhelm Göring. in Trial of the Major War Criminals before the International Military Tribunal. Vol 2. Nuremberg. 14 November 1945 - 1 October 1946 (1947) p. 99. Disponible en: https://www.loc.gov/rr/frd/Military_Law/pdf/NT_Vol-II.pdf

21 KELLY, Michael J; MCCORMAC, Timothy. Contributions of the Nuremberg Trial to the Subsequent Development of International Law. in The Legacy of Nuremberg: Civilizing Influence or Institutionalized Vengeance? p. 108.

22 The Tribunal is of the opinion that revolting and horrible as many of these crimes were, it has not been satisfactorily proved that they were done in execution of, or in connection with, any such crime. The Tribunal therefore cannot make a general declaration that the acts before 1939 were Crimes against Humanity within the meaning of the Charter, but from the beginning of the war in 1939 War Crimes were committed on a vast scale, which were also Crimes against Humanity; and insofar as the inhumane acts charged in the Indictment, and committed after the beginning of the war, did not constitute War Crimes, they were all committed in execution of, or in connection with, the aggressive war, and therefore constituted Crimes against Humanity." TMI. The Trial of German Major War Criminals: Before the International Military Tribunal. Vol. 1. Germany. 1947, p. 254. 
filo, ya que algunos autores han considerado que la inclusión de los crímenes contra la humanidad fue restringida exclusivamente al contexto de un conflicto armado internacional, y no fue hasta 1998 con el Estatuto de Roma que los Estados reconocieron que los crímenes en contra de la humanidad pueden suceder inclusive en tiempos de paz. ${ }^{23}$

Durante la defensa de Hermann Wilhelm Göring, ${ }^{24}$ también se alegó que obligaciones internacionales no eran crímenes frente a los cuales pudiera imputarse responsabilidad a los acusados, frente a lo cual el Tribunal afirmó lo siguiente:

It is argued that the Pact does not expressly enact that such wars are crimes, or set up courts to try those who make such wars. To that extent the same is true with regard to the laws of war contained in the Hague Convention. The Hague Convention of 1907 prohibited resort to certain methods of waging war. These included the inhumane treatment of prisoners, the employment of poisoned weapons, the improper use of flags of truce, and similar matters. Many of these prohibitions had been enforced long before the date of the Convention; but since 1907 they have certainly been crimes, punishable as offences against the laws of war; yet The Hague Convention nowhere designates such practices as criminal, nor is any sentence prescribed, nor any mention made of a court to try and punish offenders. For many years past, however, military tribunals have tried and punished individuals guilty of violating the rules of land warfare laid down by this Convention. In the opinion of the Tribunal, those who wage aggressive war are doing that which is equally illegal, and of much greater moment than a breach of one of the rules of the Hague Convention25

Según el TMI, aunque de manera expresa las obligaciones internacionales no son de tipos penales en estricto sentido, si prohíben ciertas prácticas y actividades. Por ejemplo, frente a las obligaciones de conducción de hostilidades o derecho de la guerra, se consideró que estas no se encuentran reguladas exclusivamente en los tratados internacionales, sino que están presentes en la costumbre internacional y en los principios de derecho gradualmente reconocidos por los Estados. Esto supone que los destinatarios de las obligaciones consignadas en los tratados internacionales no son necesariamente sólo los Estados, sino que también pueden serlo otros sujetos como los individuos. Lo que representa que el DI no es estático, puesto que se adapta a las necesidades de los Estados, ya que hasta ese momento los crímenes de guerra solo habían sido juzgados ante jueces nacionales. ${ }^{26}$

Lo anterior es acorde con la noción según la cual, los individuos tienen deberes concretos frente al DI, ya que muchas de las normas de DIH dan lugar a la responsabilidad individual y no

$23 \quad$ CLAPHAM, Andrew. Issues of complexity, complicity and complementarity: from the Nuremberg trials to the dawn of the new International Criminal Court. in SANDS, Philippe. From Nuremberg to The Hague. Cambridge: University Press, 2003, p. 42; KELLY, Michael J; MCCORMAC, Timothy. Contributions of the Nuremberg Trial to the Subsequent Development of International Law. in The Legacy of Nuremberg: Civilizing Influence or Institutionalized Vengeance? p. 108.

24 TMI. United States et al v Hermann Wilhelm Göring. in Trial of the Major War Criminals before the International Military Tribunal. Vol 2. Nuremberg. 14 November 1945 - 1 October 1946 (1947).

25 TMI. The Trial of German Major War Criminals: Before the International Military Tribunal. Vol. 1. Germany. 1947, p. 221.

26 CRAWFORD, James. The drafting of the Rome Statute. in SANDS, Philippe. From Nuremberg to The Hague. Cambridge: University Press, 2003, p. 116; CLAPHAM, Andrew. Issues of complexity, complicity and complementarity: from the Nuremberg trials to the dawn of the new International Criminal Court. in SANDS, Philippe. From Nuremberg to The Hague. p. 31. 
únicamente de los Estados. ${ }^{27}$ Este aspecto fue controvertido por la defensa de Göring, que señaló que las obligaciones internacionales vinculaban solo a los Estados más no a los individuos. El TMI se pronunció al respecto de la siguiente manera:

Many other authorities could be cited, but enough has been said to show that individuals can be punished for violations of international law. Crimes against international law are committed by men, not by abstract entities, and only by punishing individuals who commit such crimes can the provisions of international law be enforced. ${ }^{28}$

El anterior fragmento es uno de los cambios fundamentales que presentó el TMI, ya que desde este momento existe la responsabilidad individual por actos cometidos en contra de normas de DI, quebrando de este modo con la doctrina clásica que establecía que únicamente los Estados eran sujetos pasivos de las normas internacionales. ${ }^{29}$

Además, durante la discusión para la constitución del Tribunal surgió la idea que además de procesar individuos era necesario también juzgar las organizaciones a las cuales hacían parte, y de esta manera hacer extensiva la responsabilidad por los crímenes que habían cometido, por ejemplo, otros líderes del partido Nazi. ${ }^{30}$ Y si bien al final no se llegó a este resultado, si fue uno de los criterios para seleccionar a los acusados restringiéndolos a un número de 22 acusados, pero fue una discusión frente a la posible imputabilidad de responsabilidad por crímenes internacionales a organizaciones determinadas, como el partido nazi, la Gestapo y las SS. ${ }^{31}$

Es indudable que el proceso de creación y funcionamiento del TMI fue complejo, pero los juicios realizados en contra de los líderes nazis fueron muy relevantes y generaron precedentes sumamente importantes para el desarrollo del DI y el DPI. El primero de estos avances fue el cambio de la dinámica entre el DI y los individuos, ya que, como resultado de los juicios de Núremberg, el DI se había vuelto vinculante y exigible a los individuos. Pero esto tiene dos facetas ya que fue necesario diseñar procedimientos para proteger los testigos, la información clasificada y brindar la oportunidad a los acusados del derecho de una defensa razonable, en concordancia con el debido proceso. ${ }^{32}$

$27 \quad$ VAN SCHAACK, Beth. A Concise History of International Criminal Law. Santa Clara Univ. Legal Studies Research. Understanding International Criminal Law. Aspen Publishers. Paper No. 07-42. 2007, p. 22. Available at SSRN: http://ssrn.com/abstract=1016152:

28 TMI. United States et al v Hermann Wilhelm Göring. in Trial of the Major War Criminals before the International Military Tribunal. Vol 1. Nuremberg. 14 November 1945 - 1 October 1946 (1947), p. 41.

29 That international law imposes duties and liabilities on individuals as well as upon states has long been recognized . . crimes against international law are committed by men, not by abstract entities, and only by punishing individuals who commit such crimes can the provisions of international law be enforced" Judgment of the International Military Tribunal, in The Trial of German Major War Criminals: Proceedings of the International Military Tribunal sitting at Nuremberg, Germany, Part 22, London, 1950, p. 447. Ver también: ILC. Principles of international law recognized in Charter of Nierenberg Tribunal and in the judgment tribunal. vol. II. Yearbook of the International Law Commission. 1950.

30 CLAPHAM, Andrew. Issues of complexity, complicity and complementarity: from the Nuremberg trials to the dawn of the new International Criminal Court. in SANDS, Philippe. From Nuremberg to The Hague. p. 34.

31 OVERY, Richard, The Nuremberg trials: international law in the making. in SANDS, Philippe. From Nuremberg to The Hague, p. 12.

32 MALEY, William. The Atmospherics of the Nuremberg Trial. in The Legacy of Nuremberg: Civilizing Influence or Institutionalized Vengeance? Leiden: Martinus Nijhoff Publishers, 2008, p. 8. 
Por ejemplo, en el caso del juicio del Almirante Karl Dönitz, la defensa argumentó que las prácticas navales empleadas por el acusado eran acordes a las leyes de la guerra naval, apoyándose en testimonios de otros almirantes de los Estados aliados, lo que llevo al TMI a determinar que el Almirante Dönitz, no era culpable de los cargos que le habían sido imputados. ${ }^{33}$

Otro de los aspectos más destacables fue que se determinó una prioridad del DI sobre el interno, ya que en muchos casos las conductas por las que fueron juzgadas los oficiales alemanes estaban autorizadas por el derecho doméstico, superando así la visión tradicional del DI que se restringía únicamente a las relaciones entre los Estados, y afianzando la idea de que las violaciones a las normas de DIH pueden ser juzgadas independientemente de si están o no prohibidas por el derecho interno. En palabras del Juez de la Corte Internacional de Justicia Christopher Greenwood:

Nuremberg represented the end of the notion of unlimited national sovereignty, a new international set of norms of conduct becoming applicable, compliance with superior orders ceased to be a defense and after Nuremberg the illegality of aggressive war was well

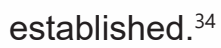

A pesar de los importantes aportes del TMI no se puede ignorar el hecho que los crímenes juzgados en Núremberg fueron introducidos de manera posterior a la creación de los Estatutos, lo cual es controversial a la luz del principio de legalidad. Sin embargo, el TMI consideró que el principio de nullum crimen sine lege no era aplicable debido a la ilicitud obvia de los actos cometidos por las personas juzgadas. ${ }^{35}$ Posteriormente, los principios de DI desarrollados por el Tribunal fueron confirmados por la AGNU, a través de Resolución 95 aprobada el 11 de diciembre de 1946 (que reafirmaba los principios de DI reconocidos por el Tribunal de Núremberg), ${ }^{36}$ y esta aprobación supuso que la comunidad internacional había reconocido las consideraciones del Tribunal en principios generales de derecho con carácter vinculante para los Estados.

Pero como era evidente el TMI de Núremberg no estuvo exento de críticas, ya que debido a su carácter experimental se ha señalado que los Tribunales fueron principalmente un acto político de las naciones vencedoras sobre los vencidos, siendo que la elección de los acusados y de los crímenes fue muy arbitraria. ${ }^{37}$ Además uno de los cuatro estados fiscales, la Unión Soviética, era culpable de tres de los cuatro cargos creados por el TMI, y los cuales había cometido deliberadamente en su propio nombre en la década anterior.

33 MALEY, William. The Atmospherics of the Nuremberg Trial. in The Legacy of Nuremberg: Civilizing Influence or Institutionalized Vengeance? p. 08.

34 MALEY, William. The Atmospherics of the Nuremberg Trial. in The Legacy of Nuremberg: Civilizing Influence or Institutionalized Vengeance? p. 9.

35 "...principle of legality, defined in international law through the maxim nullum crimen sine lege, nulla poena sine lege, which dictates that an individual cannot be prosecuted for conduct that was not criminalized at the time the individual acted... The Nuremberg Tribunal in particular ruled that the defense was inapplicable in light of the obvious wrongfulness of the acts in question." MALEY, William. The Atmospherics of the Nuremberg Trial. in The Legacy of Nuremberg: Civilizing Influence or Institutionalized Vengeance? p. 35.

36 Affirmation of the Principles of International Law Recognized by the Charter of the Nürnberg Tribunal, GA Res 95 (I), UN Doc A/RES/95 (I), 11 December 1946.

37 The choice of defendants and the definition of the charges were arbitrary. 
No obstante, los Tribunales fueron un avance fundamental para el DI contemporáneo, en palabras de Graham T. Blewitt, fiscal del TPIY, "the Nuremberg process and its legacy have contributed to the development of the human race, by achieving another step in becoming more civilized, and thus reaching a higher level in our development as a species." 38 Además, se ha señalado a los TMI de ser un "momento Grociano", es decir representaron un cambio fundamental en el sistema internacional, en un período muy corto de tiempo durante el cual se introdujeron nuevos principios de costumbre internacional. ${ }^{39}$

Por ultimo vale la pena agregar, que el TMI también fue un mecanismo de conjugar los demonios del nazismo en el proceso de posguerra, además algunos autores consideran que las víctimas y sobrevivientes de los crímenes de estos crímenes internacionales, son más propensos a perdonar y permitir que se produzca la reconciliación, sin recurrir a actos de venganza, siempre y cuando se logre justicia. ${ }^{40}$ Inclusive más de 70 años después de la Segunda Guerra Musical y de la sentencia dictada por el TMI de Núremberg, lo dicho por el Tribunal y los principios desarrollados continua siendo muy relevantes frente al DI, ya que significó que este no es estático sino que se adapta las necesidades de un mundo cambiante y de cara al DPI representó el inicio de la posibilidad de juzgar individuos ante un tribunal internacional por la violación de normas internacionales.

\section{TRIBUNALES AD HOC TYPY Y TPIR}

El segundo de los antecedes que se analizará es la constitución de los Tribunales ad hoc de Yugoslavia (TPIY) y Ruanda (TPIR), los cuales fueron creados en la década de los 90 como respuesta por parte de la comunidad internacional a algunos de los crímenes más graves cometidos a finales del siglo XX. Los tribunales ad hoc fueron establecidos por el CSNU en virtud del capítulo VII de la Carta de la ONU, ${ }^{41}$ con el objetivo de mantener la paz y enjuiciar a los máximos responsables de graves violaciones del DIH, además de ayudar a garantizar que esas violaciones no se repetirían y se reparasen eficazmente a las victimas. Siendo ellos referentes sui generis ya que, si bien como instrumento puede asemejarse a un tratado, su naturaleza jurídica la hace muy diferente. ${ }^{42}$

\footnotetext{
38 MALEY, William. The Atmospherics of the Nuremberg Trial. in The Legacy of Nuremberg: Civilizing Influence or Institutionalized Vengeance? p. 8.

39 "Nuremberg constituted what some commentators call "a Grotian Moment" - an instance in which there is such a fundamental change to the international system that a new principle of customary international law can arise with exceptional velocity. This was the first time in history that the term was used in a proceeding before an international court." SCHARF, Michael P. Seizing the "Grotian Moment: Accelerated Formation of Customary International Law in Times of Fundamental Change.. Cornell International Law Journal. Vol. 43, 12 de april de 2010, p. 439 ; Case Legal Studies Research Paper No. 2010, p. 442. Disponible en SSRN: http://ssrn.com/abstract=1588283

40 BLEWITT, Graham. The Importance of a Retributive Approach in SANDS, Philippe. From Nuremberg to The Hague. p. 39.

41 SCHABAS, William. The UN International Criminal Tribunal: The Former Yugoslavia, Rwanda and Sierra Leone. Cambridge: University Press. 2006, p. 78.

42 SCHABAS, William. The UN International Criminal Tribunal: The Former Yugoslavia, Rwanda and Sierra Leone. p. 79.
} 
El primer Tribunal ad hoc fue el TPIY, establecido mediante la Resolución 827 de 1993 del CSNU, ${ }^{43}$ con el objetivo de enjuiciar a los presuntos responsables de graves violaciones del derecho intencional humanitario cometidas en el territorio de la ex República de Yugoslavia. ${ }^{44}$ La idea del Tribunal surgió desde 1989, pero se fue afianzando con base en los informes sobre violaciones de derechos humanos en los territorios de la ex República de Yugoslavia que habían sido remitidos por la Comisión de Expertos establecida mediante la Resolución 780 de $1992 .{ }^{45}$ Frente a estos hechos se determinó la posibilidad de crear un tribunal criminal bajo la premisa de que un juicio puede contribuir a la construcción de la paz en la región. ${ }^{46}$

Una vez se conocieron los informes de la Comisión de expertos, el CSNU reconoció que el conflicto en la ex República de Yugoslavia era una amenaza en contra de la paz y la seguridad, y en 1993 tomó la decisión con base en el Capítulo VII de la ONU de crear el tribunal ad hoc como una medida eficaz para preservar la paz y la seguridad. ${ }^{47}$ Este Tribunal se regía por su propio estatuto anexo a la Resolución del CSNU, ${ }^{48}$ y se encontraba situado en los Países Bajos, lo cual fue uno de los aspectos criticados. ${ }^{49}$

Según Gideon Boas, el TPIY representó el primer intento de crear un código de procedimiento y pruebas coherentes y creíbles para el enjuiciamiento de la conducta delictiva internacional y, en particular, el juzgamiento por violaciones del derecho internacional humanitario. ${ }^{50} \mathrm{~A}$ diferencia del número reducido de personas juzgadas en el TMI de Núremberg, el TPIY juzgó a más de 161 personas de diferentes grupos étnicos de los estados de Croacia, Serbia, Bosnia, Kosovo, incluyendo a individuos de varios niveles de la sociedad (no exclusivamente altos funcionarios), debido a que en la Resolución 827 no se hacía referencia expresa al nivel o posición de los posibles responsables, sino al juzgamiento de todos los responsables de violaciones graves del DIH. ${ }^{51}$

43 CSNU. Resolución 827 de 1993, adoptada el 25 de mayo de 1993, disponible en: http://www.icty.org/x/file/Legal\%20Library/Statute/ statute_827_1993_en.pdf

44 CSNU. Resolución 827 de 1993, adoptada el 25 de mayo de 1993, disponible en: http://www.icty.org/x/file/Legal\%20Library/Statute/ statute_827_1993_en.pdf

45 The Security Council instructed a Commission of Experts to investigate the situation in Rwanda in the same manner it had acted in the case of Yugoslavia and, on the basis of the Commission's reports, it determined that there was a threat to international peace and security, p. 340 .

46 BOAS, Gideon; SCHABAS, William. International Criminal Law Developments in the Case Law of the ICTY. Netherlands: Martinus Nijhoff Publishers, 2003, p. 4.

47 BLEWITT, Graham. The Importance of a Retributive Approach in SANDS, Philippe. From Nuremberg to The Hague. p. 44 . Ver también las siguientes resoluciones 808 (1993), UN Doc S/RES/808 (1993), 22 de febrero 1993; SC Res 827 (1993), UN Doc S/RES/827 (1993), 25 mayo 1993.

48 CSNU. Statute of the International Criminal Tribunal for the former Yugoslavia, anexo a la Resolucion 827, 1993. UN Doc S/RES/827 (1993) (adopted 25 May 1993, as amended 19 May 2003) ('Statute of the ICTY');

49 CHIAM, Madelaine. Different Models of Tribunals. The Legacy of Nuremberg: Civilising Influence or Institutionalised Vengeance? Leiden: Martinus Nijhoff Publishers. 2008, p. 207; ver también: ALVAREZ, Jose. Crimes of States/Crimes of Hate: Lessons from Rwanda. Yale Journal of International Law. 2009, p 365.

50 BOAS, Gideon; SCHABAS, William. International Criminal Law Developments in the Case Law of the ICTY. p. 2.

51 Aunque esto no fue absoluto para todas las partes en el conflicto de los Balcanes, en tanto, no se permitió el juzgamiento de los miembros de las fueras de E.E.U.U. por los bombardeos realizados como parte del destacamento de la OTAN. RALSTON, John; FINNIN, Sarah. Investigating International Crimes: A Review of International Law Enforcement Strategies Blumenthal. in David. \& McCormack, Timothy L.H. The Legacy of Nuremberg: Civilizing Influence or Institutionalized Vengeance? p. 53. 
Fue claro desde el principio que de acuerdo con el objeto de la Resolución 827 de 1993, el número de acusados sería demasiado grande, pero tampoco podría centrarse exclusivamente en los líderes de las organizaciones, ya que esto pudo ser visto como una puerta abierta a la impunidad de sujetos que se encontraba en un mando intermedio que presuntamente era responsables de graves crímenes internacionales. ${ }^{52}$ Por lo tanto, el TPIY se enfocó en tres posibles acusados: I) aquellos que tenían mayor responsabilidad por violaciones graves del derecho internacional humanitario, incluidos los sujetos que ocuparan puestos de liderazgo, II) los delincuentes más notorios, y III) los responsables de la violencia sexual atroz..$^{53}$ Esto debido a que la responsabilidad planteada por en el Estatuto del Tribunal no se limitaba a un número determinado de sujetos sino a la gravedad de los delitos. ${ }^{54}$

La competencia del TPIY se encontraba determinada a los hechos ocurridos en ex Yugoslavia desde 1991 hasta el verano de 1992, época en que sucedieron los crímenes alegados y conducen a la Sala de Apelación a concluir que los crímenes imputados fueron cometidos con ocasión de un conflicto armado. Así mismo, el marco geográfico y temporal de referencia era igualmente amplio, ya que cubriría a las personas objeto de protección del artículo 3 común de los Convenios de Ginebra, es decir, no son sólo quienes están directamente ligadas a los escenarios de combate. ${ }^{55}$

El TPIY introdujo importantes avances para el desarrollo del Derecho Internacional, al establecer los criterios para determinar la existencia de un conflicto armado lo cual es relevante al momento de determinar la existencia de un crimen internacional de terrorismo, por cuanto, muchos actos terroristas suceden en ese contexto. ${ }^{56}$ Dicho esto, ahora se tiene un parámetro mucho más claro para la aplicación de normas de DIH, igual de importante fue la supresión de los límites entre un conflicto armado internacional y uno no internacional, toda vez que los crímenes cometidos en los escenarios de confrontación en las exrepúblicas yugoslavas se desarrollaron ambos tipos de conflictos armados. Por ejemplo, en el caso (Prosecutor v. Dusko Tadic) se establecieron criterios para determinar la existencia de un conflicto armado de la siguiente manera:

\footnotetext{
52 BLEWITT, Graham. The Importance of a Retributive Approach in SANDS, Philippe. From Nuremberg to The Hague p. 44.

53 RALSTON, John; FINNIN, Sarah. Investigating International Crimes: A Review of International Law Enforcement Strategies Blumenthal. in David. \& McCormack, Timothy L.H. The Legacy of Nuremberg: Civilizing Influence or Institutionalized Vengeance? p. 53.

54 "Initially, the jurisdiction of the ad hoc Tribunals was delimited by concentrating on those responsible for the most serious crimes; jurisdiction was not limited to individuals in positions of authority, or limited by any reference to their degree of culpability. By 2004, however, the focus had moved away from the gravity of the crime, to the gravity of the responsibility." RALSTON, John; FINNIN, Sarah. Investigating International Crimes: A Review of International Law Enforcement Strategies Blumenthal. in David. \& McCormack, Timothy L.H. The Legacy of Nuremberg: Civilizing Influence or Institutionalized Vengeance? p. 51.

55 ICTY, Appeals Chamber Decision. Prosecutor v. Dusko Tadic. 1997, p. 73; ver también; APONTE, Alejandro. Persecución penal de crímenes internacionales: diálogo abierto entre la tradición nacional y el desarrollo internacional. Grupo Editorial Ibáñez. 2010, p. 29. 
Existe un conflicto armado siempre que se apele a la fuerza armada entre los Estados o violencia armada prolongada entre las autoridades gubernamentales y grupos armados organizados, o entre tales grupos dentro de un Estado. El derecho internacional humanitario se aplica desde el inicio de tales conflictos armados y se extiende más allá de la cesación de hostilidades hasta que se celebra un tratado general de paz; o, en el caso de conflictos internos, se alcanza un acuerdo de paz. Hasta ese momento, el derecho internacional humanitario continúa aplicándose en el territorio entero de los Estados en guerra o, en el caso de conflictos internos, todo el territorio bajo control de una parte, si ahí tiene lugar o no un combate real. ${ }^{57}$

Pero no fue la única contribución de este caso, según Kai Amos en la decisión sobre jurisdicción emitida por la Cámara de Apelaciones del TPIY se determinaron las condiciones para que se configure un crimen de derecho internacional, las cuales son: I) una prohibición de una conducta determinada con una definición consensuada (no ambigua) en el ámbito internacional, II) el quebrantamiento de esta prohibición debe suponer una violación grave de valores universales y producir una preocupación colectiva entre la comunidad internacional III) que el mencionado acto por sí mismo suponga la responsabilidad penal individual, es decir, que la prohibición tenga efectos directamente vinculante, ${ }^{58}$ aunque este aspecto se tratará más a fondo en la parte IV del documento.

EI TPIY también advirtió que para la existencia conflicto armado de carácter no internacional (interno), deben ser analizados dos criterios establecidos en el caso (Prosecutor $v$. Dusko Tadic) los cuales son: (I) la intensidad del conflicto y (II) el nivel de organización de las partes. De otro lado, precisó que estos criterios se utilicen con el propósito de distinguir un conflicto armado de otros tipos de actos violentos que no estaban vinculados directamente al amparo del $\mathrm{DIH} .{ }^{59} \mathrm{Y}$ para el caso (Prosecutor v. Fatmir Limaj y otros) el TPIY imputó diversos delitos cometidos bajo el contexto de conflicto armado interno, por conductas como la detención de civiles bajo condiciones inhumanas, torturas y actos inhumanos y degradantes ${ }^{60}$. Determinado que los hechos por los cuales fueron acusados estaban vinculados al conflicto armado interno que se desarrollaba, con base en el artículo tercero del Estatuto del TPIY. ${ }^{61}$

Esto resulta de mayor importancia por cuanto una de las discusiones más relevantes es establecer si un acto de terrorismo puede considerarse como un delito autónomo que se desarrollan en el marco de un conflicto armado (internacional o interno), lo cual se analizará en el Capítulo IV. Sin que esto impida que también este tipo de acciones puedan caracterizarse al mismo tiempo como

57 "an armed conflict exists whenever there is a resort to armed force between States or protracted armed violence between governmental authorities and organized armed groups or between such groups within a State”. ICTY. Appeals Chamber Decision. Prosecutor v. Dusko Tadic. 1997, p. 141-142.

58 AMOS, Kai. Terrorismo y Derecho Penal. Berlín: Konrad-Adenauer-Stiftung. 2015, p. 33.

59 ICTY. Appeals Chamber Decision. Prosecutor v. Dusko Tadic. 1997, p. 141-142; APONTE, Alejandro. Persecución penal de crímenes internacionales: diálogo abierto entre la tradición nacional y el desarrollo internacional. p. 34.

60 STAFFEN, Márcio Ricardo; CALLETI, Leandro (2017). Da necessidade de uma universalidade rediviva para os direitos humanos. Revista de Direito Brasileira, n. 16, n. 7, dez. 2017, p. 96-114.

61 STAFFEN, Márcio Ricardo; CALLETI, Leandro (2017). Da necessidade de uma universalidade rediviva para os direitos humanos. Revista de Direito Brasileira, n. 16, n. 7, dez. 2017, p. 96-114. 
crimen de lesa humanidad. Toda vez que existe la posibilidad que simultáneamente se presente un crimen de guerra y de lesa humanidad, según se analizó en el caso (Prosecutor v. Fatmir Limaj y otros). Siempre y cuando los hechos sean parte de un ataque sistemático y generalizado en contra de la población civil. Y si bien, no se requiere de un nexo con el conflicto, sí es necesario que las acciones fueran cometidas durante el desarrollo del conflicto armado.

Frente al terrorismo, el tribunal realizo un pronunciamiento en el caso Prosecutor c Stalisnav Galic, en el cual, el Comandante de las tropas de Sarajevo, Stalisnav Galic, fue acusado de actos deliberados de terrorismo en contra de los habitantes de Sarajevo, acudiendo a una de las subcategorías de los crímenes de guerra, establecidos en el artículo 51 del artículo 3.62 Es decir, realizar actos de violencia directa en contra de personas que no toman parte del conflicto armado con el fin último de difundir terror en contra de la población civil.63

EI TPIY fue fundamental para el avance del DI y sobre cuestiones relativas al terrorismo, como la existencia de actos de terrorismo dentro de un conflicto armado que también represento un ejercicio autónomo por parte del CSNU para enfrentar las amenazas contra la paz y seguridad de una región. Pero no fue el único tribunal ad hoc constituido durante la década de los noventa, ya que, a causa de las atrocidades cometidas en Ruanda, entre abril y julio de 1994, y con el objetivo de enjuiciar a los responsables de las infracciones contra el DIH y del crimen de genocidio. EI CSNU, mediante la Resolución 955 de 1994 creó el Tribunal Penal Internacional para Ruanda (TPIR), adoptando el modelo previamente utilizado en el TPIY. ${ }^{64}$ Pero tomando en cuenta las particularidades del conflicto en el país africano. ${ }^{65}$

Como se mencionó, el Tribunal Penal Internacional para Ruanda fue constituido el 8 de noviembre de 1994 por la Resolución No. 955 del CSNU, con el objetivo de contribuir al restablecimiento y al mantenimiento de la paz en Ruanda y de favorecer la reconciliación nacional. Tiene similitudes con TPIY, ya que el estatuto tampoco hacía referencia a alguna a quiénes podrían ser los posibles acusados, ni su posición dentro de gobierno del país africano, su jerarquía en el Ejército o los grupos responsables, ni tampoco el nivel de responsabilidad, ya que el objetivo de juzgamiento nuevamente se encontraba abierto a las graves violaciones del derecho internacional humanitario. ${ }^{66}$

62 ICIY, Prosecutor v. Stanislav Galic, Case No. r-98-29-T, Judgment and Opinion, 5 Dec. 2003.

63 "Acts of violence directed against the civilian population or individual civilians who are not taking direct part in hostilities causing death or serious injury to body or health within the civilian population."

64 persons responsible for genocide and other serious violations of international humanitarian law committed in the territory of Rwanda and Rwandan citizens responsible for genocide and other such violations committed in the territory of neighbouring States, between 1 January 1994 and 31 December 1994" CSNU, Res 955 de 1994, Noviembre 1994; ver también RALSTON, John; FINNIN, Sarah. Investigating International Crimes: A Review of International Law Enforcement Strategies Blumenthal. in David. \& McCormack, Timothy L.H. The Legacy of Nuremberg: Civilizing Influence or Institutionalized Vengeance? p. 56.

65 RALSTON, John; FINNIN, Sarah. Investigating International Crimes: A Review of International Law Enforcement Strategies Blumenthal. in David. \& McCormack, Timothy L.H. The Legacy of Nuremberg: Civilizing Influence or Institutionalized Vengeance? p. 56.

66 "Art. 1. The International Tribunal for Rwanda shall have the power to prosecute persons responsible for serious violations of international humanitarian law committed in the territory of Rwanda and Rwandan citizens responsible for such violations committed in the territory of neighbouring States, between 1 January 1994 and 31 December 1994, in accordance with the provisions of the present Statute." Security Council resolution 955. 1994. 
Sin embargo, de las acusaciones emitidas por los fiscales del Tribunal, se sugiere que se adoptó una estrategia que se centraba en: I) los líderes políticos, como Jean Kambanda (el ex primer ministro de Ruanda), los ministros y alcaldes; II) Responsables en los medios de comunicación; ${ }^{67}$ III) figuras clave de las Distritos más afectados; ${ }^{68}$ y IV) sujetos responsables por conductas graves. ${ }^{69}$

Es importante resaltar que el caso de Ruanda se discutió si efectivamente existía un conflicto armado no internacional, en el momento en que ocurrió el genocidio, ya que los hechos no se enmarcaban claramente en lo dispuesto por el artículo 3 común de los Convenios de Ginebra. Razón por la cual el TPIR, en el caso (Prosecutor v. Georges Anderson Nderubumwe Rutaganda) consideró que la existencia de un conflicto armado debe decidirse en cada caso concreto, y de manera independiente, otorgándole al juez la prerrogativa para determinar la naturaleza del realizar el juzgamiento. ${ }^{70} \mathrm{Y}$ en el caso (Prosecutor v. Jean Paul Akayesu), el Tribunal subrayó que el objetivo del artículo 3 común era el de proteger a las víctimas del conflicto armado y, por lo tanto, la aplicación del DIH no era sujeto de variación por las partes del conflicto, ya que esto conllevaría a que el conflicto fuera minimizado. ${ }^{71}$

Ahora bien, las Resoluciones 827 de 1993 y 955 de 1994, que constituyeron los Tribunales ad hoc examinados, fueron respuestas a las necesidades de la comunidad internacional para evitar la impunidad en dos de las tragedias más grandes de los años 90 y de procesar a las personas responsables de violaciones graves del DIH. Ha de considerarse además que tales enjuiciamientos pueden contribuir a que violaciones de aquella índole no se repitan, contribuyendo al proceso de reconciliación nacional y al restablecimiento y mantenimiento de la paz de los Estados afectados. ${ }^{72}$

Los tribunales $A d$ hoc representan antecedentes fundamentales que reforzaron la legitimidad del sistema internacional y su capacidad para juzgar individuos ante órganos judiciales internacionales. Además, articularon principios internacionales, algunos de los cuales posteriormente se recogerían en el Estatuto de la CPI. Por ende, los tribunales ad hoc le confirmaron a la comunidad internacional (después de 50 años de los TMI) que sí era posible investigar, juzgar y sancionar las graves violaciones a normas de DI.

67 ICTR, Appeals Chamber Decision, Prosecutor v Jean-Bosco Barayagwiza, Case No ICTR-99-52; disponible: http://www.un.org/en/ preventgenocide/rwanda/pdf/NAHIMANA\%20ET\%20AL\%20-\%20APPEALS\%20JUDGEMENT.pdf

68 ICTR, Appeals Chamber Decision, Prosecutor v Pauline Nyiramasuhuko, 2015 Case No ICTR-98-42 disponible: http://www.europeanrights. eu/public/provvedimenti/OKRUANDA-ICTR___Nyiramasuhuko_et_al.pdf

69 Un caso reseñado por algunos autores fue e el de un sacerdote católico. ICTR, Appeals Chamber Decision, Prosecutor v Athanase Seromba, 2010. Disponible: http://hrlibrary.umn.edu/instree/ICTR/SEROMBA_ICTR-2001-66/SEROMBA_ICTR-2001-66-A.pdf

70 "The Chamber notes the finding made in the Kayishema and Ruzindana Judgement, whereby the term nexus should not be defined in abstract. Rather, the evidence adduced in support of the charges against the accused must satisfy the Chamber that such a nexus exists. Thus, the burden rests on the Prosecutor to prove beyond a reasonable doubt that, on the basis of the facts, such a nexus exists between the crime committed and the armed conflict." ICTR, Prosecutor v. Rutaganda. 1999, p. 104-105.

71 ICTR, Prosecutor v. Rutaganda. 1999, p. 99-101

72 CHIAM, Madelaine. Different Models of Tribunals. The Legacy of Nuremberg: Civilising Influence or Institutionalised Vengeance? $p$. 207. 
Pero aquellos órganos no estuvieron exentos de críticas, ya que de manera similar al TMI de Núremberg se señaló que las decisiones del TPIR vulneraban el principio de nullum crimen sine lege. Al respecto, la Cámara de apelaciones dijo lo siguiente en el caso del Prosecutor v. Georges Anderson Nderubumwe Rutaganda:

In applying Article 4 of the Statute, the Chamber must be satisfied that the principle of nullum crimen sine lege is not violated. Indeed, the creation of the Tribunal, in response to the alleged crimes perpetrated in Rwanda in 1994, raised the question all too familiar to the Nuremberg Tribunal and the ICTY, that of jurisdictions applying ex post facto laws in violation of this principle. In establishing the ICTY, the Secretary-General dealt with this issue by asserting that in the application of the principle of nullum crimen sine lege the International Tribunal should apply rules of international humanitarian law which are beyond any doubt part of customary law. However, in the case of this Tribunal, it was incumbent on the Chambers to decide whether or not the said principle had been adhered to, and whether individuals incurred individual criminal responsibility for violations of these international instruments. ${ }^{73}$

Por otra parte, durante los juicios se les otorgó a los jueces de cada Tribunal un amplio margen de interpretación para determinar, en cada caso, si existían o no los elementos suficientes para "activar" el sistema de responsabilidad internacional, por ejemplo, al momento de determinar la existencia de un conflicto armado internacional (o no internacional) o inclusive para establecer los elementos de ataques inciertos en una política sistemática y generalizada para poder establecer la existencia de crímenes de lesa humanidad. ${ }^{74}$

Algunos autores consideran que los Tribunales ad hoc fueron demasiado costosos e ineficientes como mecanismos de justicia en sociedades con escenarios de posconflicto, y que ejemplifican un enfoque que ya no es viable ni desde un punto de vista político ni financiero. ${ }^{75}$ Por ejemplo, se ha sugerido que el dinero invertido en el funcionamiento del TPIR pudo haber sido utilizado en la reconstrucción el sistema judicial ruandés, lo que hubiera permitido juzgar a un número mucho mayor de individuos (que aún se encuentran pendientes de ser procesados) que los juzgados por el Tribunal internacional. ${ }^{76}$

Otros aspectos criticados fueron los relativos a la ubicación y composición de los Tribunales ad hoc. En un principio se consideró que al no encontrarse sus instalaciones en los lugares donde se cometieron los crímenes y que, con el nombramiento de jueces, abogados e investigadores extranjeros, se aumentaría la idea de imparcialidad y la credibilidad de los procedimientos realizados

\footnotetext{
$73 \quad$ ICTR, Prosecutor v. Rutaganda. 1999, p. 83.

74 RALSTON, John; FINNIN, Sarah. Investigating International Crimes: A Review of International Law Enforcement Strategies Blumenthal. in David. \& McCormack, Timothy L.H. The Legacy of Nuremberg: Civilizing Influence or Institutionalized Vengeance? p. 56; APONTE, Alejandro. Persecución penal de crímenes internacionales: diálogo abierto entre la tradición nacional y el desarrollo internacional. Grupo Editorial Ibáñez. 2010, p. 48.

75 ZACKLIN, Ralph. The Failings of Ad Hoc International Tribunals. Journal of International Criminal Justice. 2004, p. 541-545.

76 CHIAM, Madelaine. Different Models of Tribunals. The Legacy of Nuremberg: Civilising Influence or Institutionalised Vengeance? $p$. 210.
} 
por los Tribunales. ${ }^{77}$ Sin embargo, lo anterior dio lugar a una profunda falta de conexión entre los Tribunales y el contexto interno de los casos analizados, lo que se ha traducido en que la que las poblaciones de Ruanda y de la antigua Yugoslavia no conocían las leyes, idiomas y procedimientos de los Tribunales, lo que agravaba la falta de comprensión y desinformación por parte de las víctimas, afectado la legitimidad de los juicios. ${ }^{78}$

A pesar de las críticas que despertaron los Tribunales ad hoc, ellos fueron muy importantes dada su capacidad de proporcionar un grado de justicia, frente a derechos erga omnes de interés para la comunidad internacional como para las víctimas, además de haber condenado a muchos de los responsables de crímenes graves cometidos en la década de los 90, actuando de conformidad con normas internacionales y garantías del debido proceso, y haber logrado un éxito razonable en el juzgamiento de funcionarios de alto rango, tanto en Ruanda como en la ex república de Yugoslavia. ${ }^{79}$ Además los TPIR y TPIY contribuyeron al restablecimiento y mantenimiento de la paz y al estado de derecho en esas regiones, cada vez, que los conflictos en las regiones se han vuelto prácticamente inexistentes o de mucha menor intensidad en el caso del país africano.

Lo anterior refleja cómo el juzgamiento de individuos por violaciones graves de las obligaciones internacionales puede ser eficaces para generar condiciones que conduzcan hacia la paz y la reconciliación. ${ }^{80}$ Contrariamente a las afirmaciones de los críticos, los resultados de los tribunales y tribunales ad hoc en los años noventa han tenido un efecto considerable. En 1998, la Asamblea General de la ONU encargó un estudio detallado sobre la eficacia y la eficiencia del TPIY y del TPIR, y en general se encontró que estaban operando con eficiencia y eficacia. ${ }^{81}$ Además, la remoción de Slobodan Milošević y Radovan Karadžić del poder en Yugoslavia, de Kambanda y Bagosora en Ruanda, son un ejemplo de la eficacia de los Tribunales ad hoc, que pueden ofrecer lecciones para otros escenarios, como en Siria o Iraq, lo que precisamente sería una campo de juzgamiento a los integrantes de grupos terroristas como Dáesh (ISIS) o al Qaeda.

Desde el establecimiento del TPIY, se ha reconocido en el derecho internacional que las violaciones del DPI en gran escala ponen en peligro los intereses internacionales de los Estados en la medida en que llegan al nivel de una amenaza a la paz y la seguridad internacionales en el sentido del Artículo 39 de la Carta de las Naciones Unidas. Y de lecciones del Tribunal Penal Internacional

77 CHIAM, Madelaine. Different Models of Tribunals. The Legacy of Nuremberg: Civilising Influence or Institutionalised Vengeance? $p$. 210; ver también: ALVAREZ, Jose. Crimes of States/Crimes of Hate: Lessons from Rwanda. Yale Journal of International Law. 2009 , p. 365.

78 "The decision to locate the ICTY in the Netherlands and the ICTR in Tanzania was made in an effort to ensure security for the participants in the trials, including witnesses, judges and prosecutors, and to guarantee the Tribunals' independence." CHIAM, Madelaine. Different Models of Tribunals. The Legacy of Nuremberg: Civilising Influence or Institutionalised Vengeance? p. 210.

79 CHIAM, Madelaine. Different Models of Tribunals. The Legacy of Nuremberg: Civilising Influence or Institutionalised Vengeance? $p$. 208.

80 Si bien es cierto que pueden existir tensiones en los Estados donde se presentaron estrás graves violaciones de normas de DI

81 GA Res 53/212, UN Doc A/RES/53/212, 18 December 1998; Report of the Expert Group to Conduct a Review of the Effective Operation and Functioning of the International Tribunal for the Former Yugoslavia and the International Criminal Tribunal for Rwanda. 11 November 1999. reproduced in UN Doc A/54/634, 22 November 1999. Disponible en: http://www.un.org/documents/ga/docs/56/a56853.pdf 
para la ex Yugoslavia y el Tribunal Penal Internacional para Ruanda, se demuestra que a través de instituciones constituidas a partir de las Resoluciones del Capítulo VII de la Carta de la ONU, resulta posible cumplir con los objetivos de mantener la paz y la seguridad sin recurrir directamente al uso de la fuerza militar. Siendo este la continuación de un camino que inició con los TMI de Núremberg, para la "enforcement" de las obligaciones del DI, a través de la aplicación del DPI.

\section{CORTE PENAL INTERNACIONAL Y LOS TRIBUNAL MIXTOS}

A diferencia de los antecedentes previamente analizados, la Corte Penal Internacional (CPI) no nace de una voluntad única del CSNU para juzgar los crímenes internacionales más graves dentro de escenarios específicos, sino que es fruto de la voluntad de los Estados para hacerse parte del Estatuto de Roma. De acuerdo con Malcolm Shaw, la idea de un tribunal internacional penal permanente surgió en 1950, cuando la AGNU a través de la Resolución 260 de 1950 le preguntó a la Comisión de Derecho Internacional la posibilidad de la existencia de un tribunal internacional con competencia para juzgar los actos de genocidio. Sin embargó, debido a motivos político, solo fue hasta 1990 que la idea de una se retomó, cuanto Trinidad y Tobago propuso la creación de un Tribunal internacional con competencia para juzgar delitos de narcotráfico. ${ }^{82}$

Frente a la anterior propuesta, en 1994 la CDI adopto el borrador del estatuto de la CPI en el cual además de los crímenes establecidos en la versión final (genocidio, crimen contra la humanidad, crímenes de guerra y de agresión) incluía como delitos el terrorismo y el tráfico de drogas, que, si bien no se encontraban expresamente establecidos, eran aplicables a través de la remisión a listado anexo del borrador. ${ }^{83}$ Y con base en el trabajo preparatorio de la CDI se llevó a cabo la Conferencia en Roma en 1998 que produjo el Estatuto de Roma, el cual entró en vigor en el año 2002 cuando fue ratificado por 60 Estados. $^{84}$

Van der Vyver, que señala que el terrorismo fue deliberadamente omitido en la materia de la jurisdicción de la CPI, en parte, debido a la propuesta de los Estados Unidos en las primeras sesiones del Comité Especial sobre una Corte Penal Internacional Permanente, solicitando expresamente

82 CRAWFORD, James. The drafting of the Rome Statute. in SAND, Philippe p. 110; SHAW, Malcolm. International Law. 6 ed. Cambridge: University Press. 2008, p. 411

83 "Article 20 Crimes within the jurisdiction of the Court The Court has jurisdiction in accordance with this Statute with respect to the following crimes: (a) the crime of genocide; (b) the crime of aggression; (c) serious violations of the laws and customs applicable in armed conflict; (d) crimes against humanity; (e) Crimes, established under or pursuant to the treaty provisions listed in the Annex, which, having regard to the conduct alleged, constitute exceptionally serious crimes of international concern. (b) Annex Crimes pursuant to treaties. 2. The unlawful seizure of aircraft as defined by article 1 of the Convention for the Suppression of Unlawful Seizure of Aircraft of 16 December 1970. 3. The crimes defined by article 1 of the Convention for the Suppression of Unlawful Acts against the Safety of Civil Aviation of 23 September 1971. 5. The crimes defined by article 2 of the Convention on the Prevention and Punishment of Crimes against Internationally Protected Persons, including Diplomatic Agents of 14 December 1973. 6. Hostage-taking and related crimes as defined by article 1 of the International Convention against the Taking of Hostages of 17 December 1979. 9. Crimes involving illicit traffic in narcotic drugs and psychotropic substances as envisaged by article 3, paragraph 1, of the United Nations Convention against Illicit Traffic in Narcotic Drugs and Psychotropic Substances of 20 December 1988 which, having regard to article 2 of the Convention, are crimes with an international dimension." 
excluir el delito de terrorismo de la jurisdicción de la materia propuesta ${ }^{85}$. Y la razón principal para esta solicitud fue que la inclusión del delito en el tribunal internacional podría minar sus propios esfuerzos e investigaciones que son llevadas a cabo dentro del sistema nacional en contra de terroristas internacionales. ${ }^{86}$

Sin embargo, durante la Conferencia llevada a cabo en la ciudad de Roma, varios Estados que posteriormente fueron signatarios del estatuto de la CPI ente ellos España, Argelia, India, Sri Lanka, Barbados, Dominica, Jamaica, Trinidad y Tobago y Turquía, presentaron propuestas para incluir efectivamente el terrorismo en las disposiciones de jurisdicción de la CPI, pero finalmente dichas propuestas no fueron acogidas por un número suficiente de delegados para apoyar la idea. Sumado a este poco apoyo por parte del comité, se encontraba el desacuerdo generalizado sobre la definición exacta y los elementos requeridos del crimen, razón por la cual, el terrorismo quedó fuera del Estatuto de Roma. ${ }^{87}$

Por las anteriores razones en el documento final del Estatuto de Roma de 1998 no se incluyó el delito de terrorismo internacional, sin embargo, frente a la presente investigación no puede ignorarse el hecho que la CPI representa uno de los avances más importantes en lo referente a la persecución penal de individuos por crímenes internacionales. Y si bien, recibientemente la CPI enfrenta una crisis por los retiros de Burundi, Sudáfrica y Rusia, no deja de ser uno de los referentes más importantes del DI.

Autores como Crawford sugieren que la CPI tuvo una acogida tan rápida entre los Estados, a pesar de la oposición de países como Estados Unidos. Por este carácter subsidiario que básicamente significa que las cortes nacionales tienen prioridad para conocer los delitos. ${ }^{88}$ Pero además del principio de complementariedad, otro de los aspectos más importantes es la temporalidad de la jurisdicción, debido a que la competencia de la CPI se activa frente a los crímenes que sean cometidos con posterioridad a la entrada en vigor del tratado contentivo. ${ }^{89}$ Lo que hace que el conocimiento de asuntos por parte de la Corte sea más difícil de alcanzar, ya que se encuentra condicionado primero a la voluntad de los Estados (suscribir el tratado) y a la inoperancia de su propio sistema judicial penal (principio de complementariedad).

El estatuto constitutivo de la CPI a diferencia de los tribunales penales internacionales anteriormente estudiados, resulta más acorde con el principio de nullum crimen sine lege, cada vez que la Corte tiene jurisdicción únicamente sobre los crímenes que sean cometidos de manera

$85 \quad$ VAN DER VYVER, Johan. Prosecuting Terrorism in International Tribunals. Emory International Law Review. Vol. 24, N. 2, 2010, p. 535

86 VAN DER VYVER, Johan. Prosecuting Terrorism in International Tribunals. Emory International Law Review. Vol. 24, N. 2, 2010, p. 535

87 VAN DER WILT, Harmen; BRABER, Inez. The case for inclusion of terrorism in the jurisdiction of the international criminal court. Amsterdam Law School Legal Studies, Research Paper N. 26, 2014. Available: https://papers.ssrn.com/sol3/papers.cfm?abstract_id=2410232 CRAWFORD, James. The drafting of the Rome Statute. in SAND, Philippe p. 111; SHAW, Malcolm. International Law. p. 413

89 Articulo 25. Estatuto de Roma 
posterior a la entrada en vigor del tratado, siendo este uno de los aspectos que más lo diferencia de los tribunales Ad hoc creados por las Resoluciones del CSNU. ${ }^{90}$ Por lo tanto, no existe una jurisdicción retroactiva de la CPI a diferencia del TPIY y del TPIR los cuales juzgaron conductas anteriores a su creación.

Frente al terrorismo internacional tenemos que durante de la creación del Estatuó de Roma no se presentaron los suficientes elementos para incluirlo como uno de los crímenes de competencia de la CPI, debido a la falta de una definición del término y de voluntad de algunos Estados para incluirlo dentro de los crímenes internacionales en el Estatuto. ${ }^{91}$ No obstante, debido a los constantes desarrollos de obligaciones frente al terrorismo encabezada por el CSNU, se generó una práctica internacional y opinio juris que puede considerarse suficiente para consolidar una idea mucho más clara de lo que es el delito de terrorismo, lo cual se ve reflejado en las consideraciones que ha realizado el Tribual Especial para el Líbano (TEL).

El Tribunal Especial para el Líbano, es la primera corte internacional que ha sido otorgada con jurisdicción ratione materiae para el terrorismo. Fue creada de conformidad con un Acuerdo entre la ONU y la República Libanesa a través de la Resolución 1664 de 2005 del Consejo de Seguridad, para investigar el asesinato en 2005 del ex primer ministro Hariri Rafiq en un atentado con bomba. ${ }^{92} \mathrm{Y}$ si bien en su naturaleza jurídica el TEL puede ser similar a los Tribunales ad hoc de Yugoslavia y Ruanda, por ser creados por mediante el uso de una resolución del CSNU, este tribunal tiene una naturaleza mixta, cada vez que los jueces que lo componen son personal internacional, pero en sus decisiones se acogen a normas establecidas en el derecho interno e internacional.

Como previamente fue expuesto en el capítulo l, el TEL en una decisión interlocutoria del 16 de febrero de 2011, estableció que los actos que pueden ser consideramos como terrorismo contienen los siguientes elementos: I) la voluntad de la comisión de un acto, II) la utilización de medios que son susceptibles de crear un peligro público y III) con la intención de crear un estado de terror. ${ }^{93}$ Específicamente la Sala de Apelaciones del TEL declaró lo siguiente:

90 SCHIFF, Benjamin. Building the International Criminal Court Statute. Cambridge: University Press, 2008, p. 85.

91 Alegría, Sry Lanka e India propusieron que se considerara el terrorismo como uno de los crímenes en contra de la humanidad sometido a la jurisdicción del a CPI, pero no fue posible debido a que: (I) el delito no estaba bien definido (II) el delito podría politizar la Corte (III) Algunos actos de terrorismo no eran lo suficientemente grave como para justificar el enjuiciamiento por un tribunal internacional (IV) enjuiciamiento y el castigo por los tribunales nacionales se consideraron más eficiente. CASSESE, Antonio. Afirmación de los Principios de Derecho Internacional Reconocidos por el Estatuto del Tribunal de Nuremberg. 2006.

92 CSNU. Resolution 1664 de 2005, ver: http://www.un.org/spanish/News/focus/tslibano/

93 Chamber of Appellations, Special Tribunal for Lebanon, Interlocutory Decision on the Applicable Law: Terrorism, Conspiracy, Homicide, Perpetration, Cumulative Charging, STL-11-01/I/AC/R176bis, 16 February 2011: "In sum, and in light of the principles enunciated above, the notion of terrorism to be applied by the Tribunal consists of the following elements: (i) the volitional commission of an act; (ii) through means that are liable to create a public danger; and (iii) the intent of the perpetrator to cause a state of terror. Considering that the elements of the notion of terrorism do not require an underlying crime, the perpetrator of an act of terrorism that results in deaths would be liable for terrorism, with the deaths being an aggravating circumstance; additionally, the perpetrator may also, and independently, be liable for the underlying crime if he had the requisite criminal intent for that crime." 
...a number of treaties, UN resolutions, and the legislative and judicial practice of States evince the formation of a general opinio juris in the international community, accompanied by a practice consistent with such opinio, to the effect that a customary rule of IL regarding the international crime of terrorism, at least in time of peace, has indeed emerged. This customary rule requires the following three key elements: (i) the perpetration of a criminal act (such as murder, kidnapping, hostage-taking, arson, and so on), or threatening such an act; (ii) the intent to spread fear among the population (which would generally entail the creation of public danger) or directly or indirectly coerce a national or international authority to take some action, or to refrain from taking it; (iii) when the act involves a transnational element. $^{94}$

Este enfoque interpretativo le permitió al TEL determinar que efectivamente existe un delito definido de terrorismo bajo el derecho internacional consuetudinario. Y si bien, para la Sala de Apelaciones no ha habido una definición ampliamente aceptada del terrorismo por la comunidad internacional, debido a la marcada diferencia de opiniones sobre el término. A través de la costumbre internacional se ha configurado una regla consuetudinaria sobre el crimen de terrorismo, la cual según Kai Amos impone, "I) la obligación de abstenerse de realizar actos de terrorismo, II) la obligación de prevenir y reprimir el terrorismo, particularmente de perseguir y juzgar a sus supuestos autores, y III) el derecho de perseguir y reprimir el crimen de terrorismo cometido en su territorio por nacionales y extranjeros, y la obligación correlativa de terceros Estados de abstenerse de objetar tal persecución y represión en contra de sus nacionales." ${ }^{195}$

Para el TEL, los delitos de terrorismo tienen elementos comunes, como son un hecho tipificado como criminal que tenga la intención de ocasionar miedo en público o autoridades gubernamentales, y que involucre algún elemento trasnacional, los cuales son muy similares a los que han sido desarrolladas por las definiciones que fueron estudiadas en el Capítulo I y que fueron proferidas por el Comité ad hoc contra el terrorismo en el año 2001. ${ }^{96}$ Para la cámara de apelaciones el hecho de que el CSNU categorizara al terrorismo como una amenaza a para la paz y la seguridad, le permitió confirmar que el terrorismo es un crimen internacional incluido por la costumbre internacional, y que supone la responsabilidad individual de los responsables. ${ }^{97}$ Por lo tanto, podemos afirmar que la decisión del Tribunal del Líbano es una contribución vital al DI, ofreciendo una explicación de la práctica estatal generalizada y la opinión opinio juris respecto del terrorismo. Que a su vez estableciendo un precedente para que los Estados, las organizaciones internacionales instauren criterios más claros para determinar y juzgar los futuros actos terroristas. Por lo que la decisión del TEL puede considerarse un importante punto de inflexión para el DPI. ${ }^{98}$

\footnotetext{
94 Chamber of Appellations, Special Tribunal for Lebanon, Interlocutory Decision on the Applicable Law: Terrorism, Conspiracy, Homicide, Perpetration, Cumulative Charging, STL-11-01///AC/R176bis, 16 February 2011: AMOS, Kai. Terrorismo y Derecho Penal. p. 33

96 Recordando que de acuerdo con el artículo 28 del estatuto de la Corte Internacional de Justica, se considera costumbre la suma de la practica internacional y la opinio juris.

97 AMOS, Kai. Terrorismo y Derecho Penal. p. 35

98 AMBOS, Kai. Judicial Creativity at the Special Tribunal for Lebanon: Is there a Crime of Terrorism under Internacional Law? Leiden: Journal of Internacional Law, vol. 24. 2011, p.154
} 
Pero el TEL no fue el único tribunal especial mixto que consideró el terrorismo como un crimen autónomo, el Tribunal Especial para Sierra Leona (TESL) fue establecido conjuntamente por el Gobierno de Sierra Leona y las Naciones Unidas, y su mandato es enjuiciar a los principales responsables de las graves violaciones del derecho internacional humanitario cometidas en el territorio de Sierra Leona a partir del 30 de noviembre de 1996, mediante la Resolución 1315 de 2000.99 Algo particular en el Estatuto del TESL es que incluye el terrorismo como uno de los crímenes sobre los cuales tiene jurisdicción, ${ }^{100}$ y fue uno de los cargos en el juicio en contra del ex presidente de la Republica de Liberia, Charles Taylor. ${ }^{101}$

El cargo se basa en el DIH, específicamente en la prohibición de violencia dirigida a difundir el terror entre la población civil durante los conflictos armados tanto internacionales como no internacionales. De manera que el Estatuto del TESL refleja el del párrafo 5 del artículo 4 del Protocolo Adicional II de 1977 de los Convenios de Ginebra que se refiere ampliamente a la prohibición de los actos de terrorismo.

La Sala de Primera Instancia en el caso de Chales Taylor sostuvo que además de las prescripciones generales referentes a los crímenes de guerra, frente a los actos de terrorismo deben establecerse los siguientes elementos:

I) Actos o amenazas de violencia contra las personas o sus bienes;

II) Que el autor haga de las personas o sus bienes, objeto de dichos actos y amenazas de violencia; y

III) Los actos o amenazas de violencia sean cometidos con el objetivo principal de difundir el terror entre las personas protegidas. ${ }^{102}$

Podemos afirmar que los tribunales internacionales han permitido el avance y la aplicación de normas de DI, que en principio era vinculantes únicamente a los Estados, pero luego fueron exigibles directamente a los individuos responsables como así lo estableció el Tribunal de Núremberg. Y aunque la responsabilidad penal individual en virtud del derecho internacional no es un fenómeno nuevo, en

$99 \quad$ CSNU. Resolution 1315 del 14 de Agosto de 2000

100 "The Special Court shall have the power to prosecute persons who committed or ordered the commission of serious violations of article 3 common to the Geneva Conventions of 12 August 1949 for the Protection of War Victims, and of Additional Protocol II thereto of 8 June 1977. These violations shall include Acts of terrorism" Statute of the Special Court for Sierra Leone, Article 3.

101 "Charles Taylor was charged with numerous acts of terrorism as a war crime under Count 1 of the Indictment, which apart from specific charges of burning, served as an umbrella count that encompassed crimes that were also charged as separate crimes under Counts 2 to 13 of the Indictment and included: killings, sexual violence, physical violence, enslavement, conscripting children under the age of 15 years and using them in hostilities and pillage." KEITH, Kirsten M.F. Deconstructing Terrorism as a War Crime: The Charles Taylor Case. Oxford Journal of International Criminal Justice. vol. 11. 2013, p. 820. Special Court for Sierra Leon, (Prosecutor c. Charles Taylor), Trial Judgment, 26 April 2012

102 "Finding that the elements of the crime of acts of terrorism under Art. 13(2) of Additional Protocol II are: (i) Acts or threats of violence; (ii) That the offender wilfully made the civilian population or individual civilians not taking direct part in hostilities the object of those acts or threats of violence; and (iii) The acts or threats of violence were carried out with the specific intent of spreading terror among the civilian population." Judgment, Taylor (SCSL-03-01-T), SCSL, Trial Chamber, 18 May 2012. 
los últimos años un sistema de justicia internacional, con componentes nacionales e internacionales, se ha cristalizado a partir de la experiencia de abordar atrocidades en los planos nacional e internacional contenidas en distintas normas de DI. Lo cual ha dado paso, a la creación de Tribunales y una Corte permanente para procesar a los responsables de quebrantar normas imperativas como la prohibición del genocidio, de cometer crimen de guerra o de lesa humanidad.

La labor de los tribunales penales internacionales especiales para la ex Yugoslavia y Ruanda, el Tribunal Especial para el Líbano, la adopción del Estatuto de la Corte Penal Internacional, junto con la práctica han sido los principales contribuyentes en la construcción de un sistema de responsabilidad personal ante la violación de normas de DI. En consecuencia, la comunidad internacional está ahora dotada de un cuerpo sustancial de derecho penal sustantivo y procesal internacional y de una serie de opciones jurisdiccionales para aplicarlo, incluso contra los más altos niveles de poder, y con respecto a los crímenes masivos. Lo cual es aplicable a crímenes como los cometidos por grupos terroristas, que, si bien plantea desafíos indudables, dada su escala, complejidad, movilidad internacional y la invisibilidad comparativa de los presuntos operadores terroristas, estas características no son totalmente sin precedentes cada vez que existen la cantidad suficientes de normas internacionales que prohíben las actividades de terrorismo.

Lo anterior sin olvidar que la autoridad y la legitimidad de los tribunales penales internacionales se derivan de normas y valores internacionales que se encuentran en constante desarrollo. Y el uso de la justicia penal nacional debe seguir siendo la norma general, mientras que los tribunales internacionales e híbridos debido al principio de complementariedad deben ofrecer alternativas de justicia en situaciones en las que la voluntad política, las instituciones, la capacidad de investigar y enjuiciar a los responsables sea inexistente o inoperante.

\section{CONCLUSIONES}

Debido a unos acontecimientos particulares, como fueron los ataques a E.E.U.U en el 2001, el CNSU con base en sus poderes implícitos profirió resoluciones vincules a los Estados de conformidad con el Capítulo VII de la Carta de la ONU. Esto generó un esquema totalmente nuevo de obligaciones internacionales para enfrentar el terrorismo, mediante el cual se requirió a los miembros de la ONU para que sometan a la justica a los responsables de dichas actividades, señalando expresamente cuales son considerados como terrorismo; lo que al mismo tiempo es un reflejo de obligaciones ya establecidas en otros instrumentos internacionales, y que representó una oportunidad para darle contenido al crimen internacional de terrorismo. 
Si bien es cierto que las fuentes normativas analizadas en el documento no son tipos penales en estricto sentido, si prohíben ciertas prácticas y actividades, y es allí donde radica la importancia de los Tribunales Penales Internacionales examinados en el Capítulo III, los cuales mostraron que es posible juzgar a individuos por vulnerar normas establecidas en tratados internacionales y normas consuetudinarias. Además, sentaron las bases para que fuera posible determinar que el crimen internacional de terrorismo es autónomo y separado de otros, como el crimen de guerra o lesa humanidad. No se ignora, por supuesto, que los resultados del TIM, los tribunales ad hoc de Yugoslavia y Ruanda, la CPI y los Tribunales Especiales han tenido un efecto considerable, al ser un ejemplo de la eficacia del DPI al juzgar a los responsables de los crímenes internacionales más graves. Sus desarrollos pueden ofrecer lecciones para otros escenarios, como por ejemplo Siria, Iraq o Nigeria, en donde pueden implementarse el juzgamiento a los integrantes de grupos terroristas como Dáesh (ISIS) o Al Qaeda y diseñarse procedimientos a través de un Tribunal ad hoc, para brindar la oportunidad a los acusados de ejercer el derecho de defesa en concordancia con el debido proceso.

Se debe reiterar que numerosas resoluciones del contraterrorismo del Consejo de Seguridad CSNU confirman que los actos de terrorismo son criminales e injustificables, y junto con los pronunciamientos de los Tribunales Penales internacionales, han contribuido a la generación del crimen internacional de terrorismo como un delito separado del crimen de guerra y lesa humanidad, rompiendo con el paradigma que supone que los destinatarios de las obligaciones consignadas en los tratados internacionales son exclusivamente sólo de los Estados, sino también pueden serlo otros sujetos, como los individuos. ${ }^{103}$

\section{REFERENCIAS BIBLIOGRÁFICAS}

ALVAREZ, Jose. Crimes of States/Crimes of Hate: Lessons from Rwanda. Yale Journal of International Law. 2009, p. 365.

AMBOS, Kai. Judicial Creativity at the Special Tribunal for Lebanon: Is there a Crime of Terrorism under Internacional Law? Leiden: Journal of Internacional Law, vol. 24. 2011, p.154

AMOS, Kai. Terrorismo y Derecho Penal. Berlín: Konrad-Adenauer-Stiftung. 2015, p. 33.

APONTE, Alejandro. Persecución penal de crímenes internacionales: diálogo abierto entre la tradición nacional y el desarrollo internacional. Grupo Editorial Ibáñez. 2010, p. 29.

BLEWITT, Graham. The Importance of a Retributive Approach in SANDS, Philippe. From Nuremberg to The Hague. Cambridge: University Press, 2003, p. 40.

BOAS, Gideon; SCHABAS, William. International Criminal Law Developments in the Case Law of the ICTY. Netherlands: Martinus Nijhoff Publishers, 2003, p. 4.

CASSESE, Antonio. Afirmación de los Principios de Derecho Internacional Reconocidos por el Estatuto del Tribunal de Nuremberg. Biblioteca de la UN. 2009, p. 01. Disponible en http://legal.un.org/avl/pdf/ha/ga_95-I/ga_95-I_s.pdf,

103 CRAWFORD, James. The drafting of the Rome Statute. in SAND, Philippe p. 116; CLAPHAM, Andrew. Issues of complexity, complicity and complementarity: from the Nuremberg trials to the dawn of the new International Criminal Court, p. 31 
CHIAM, Madelaine. Different Models of Tribunals. The Legacy of Nuremberg: Civilising Influence or Institutionalised Vengeance? Leiden: Martinus Nijhoff Publishers. 2008, p. 207; ver también: ALVAREZ, Jose. Crimes of States/Crimes of Hate: Lessons from Rwanda. Yale Journal of International Law. 2009, p 365.

CLAPHAM, Andrew. Issues of complexity, complicity and complementarity: from the Nuremberg trials to the dawn of the new International Criminal Court. in SANDS, Philippe. From Nuremberg to The Hague. p. 34.

CRAWFORD, James. The drafting of the Rome Statute. in SAND, Philippe p. 116;

CSNU. Resolución 827 de 1993, adoptada el 25 de mayo de 1993, disponible en: http://www.icty.org/x/file/Legal\%20 Library/Statute/statute_827_1993_en.pdf

CSNU. Resolution 1664 de 2005, ver: http://www.un.org/spanish/News/focus/tslibano/

CSNU. Statute of the International Criminal Tribunal for the former Yugoslavia, anexo a la Resolucion 827, 1993. UN Doc S/RES/827 (1993) (adopted 25 May 1993, as amended 19 May 2003) ('Statute of the ICTY');

ICTR, Appeals Chamber Decision, Prosecutor v Athanase Seromba, 2010. Disponible: http://hrlibrary.umn.edu/instree/ ICTR/SEROMBA_ICTR-2001-66/SEROMBA_ICTR-2001-66-A.pdf

ICTR, Prosecutor v. Rutaganda. 1999, p. 99-101

ICTY. Appeals Chamber Decision. Prosecutor v. Dusko Tadic. 1997, p. 141-142.

ILC. Principles of international law recognized in Charter of Nierenberg Tribunal and in the judgment tribunal, Yearbook of the International Law Commission. vol. II. 1950. Disponible en: http://legal.un.org/ilc/texts/instruments/ english/commentaries/7_1_1950.pdf

KEITH, Kirsten M.F. Deconstructing Terrorism as a War Crime: The Charles Taylor Case. Oxford Journal of International Criminal Justice. vol. 11. 2013, p. 820. Special Court for Sierra Leon, (Prosecutor c. Charles Taylor), Trial Judgment, 26 April 2012

KELLY, Michael J; MCCORMAC, Timothy. Contributions of the Nuremberg Trial to the Subsequent Development of International Law. in The Legacy of Nuremberg: Civilizing Influence or Institutionalized Vengeance? p. 105;

MALEY, William. The Atmospherics of the Nuremberg Trial. in The Legacy of Nuremberg: Civilizing Influence or Institutionalized Vengeance? Leiden: Martinus Nijhoff Publishers, 2008, p. 8.

MALEY, William. The Atmospherics of the Nuremberg Trial. in The Legacy of Nuremberg: Civilizing Influence or Institutionalized Vengeance? p. 35.

OVERY, Richard, The Nuremberg trials: international law in the making. in SANDS, Philippe. From Nuremberg to The Hague. Cambridge: University Press, 2003, p. 9.

RALSTON, John; FINNIN, Sarah. Investigating International Crimes: A Review of International Law Enforcement Strategies Blumenthal. in David. \& McCormack, Timothy L.H. The Legacy of Nuremberg: Civilizing Influence or Institutionalized Vengeance?, Leiden: Martinus Nijhoff Publishers, 2008, p. 48.

SANDS, Philippe. From Nuremberg to The Hague. p. 23.

SCHABAS, William. The UN International Criminal Tribunal: The Former Yugoslavia, Rwanda and Sierra Leone. Cambridge: University Press. 2006, p. 78.

SCHARF, Michael P. Seizing the 'Grotian Moment: Accelerated Formation of Customary International Law in Times of Fundamental Change. Cornell International Law Journal. Vol. 43, 12 de april de 2010, p. 439 ; Case Legal Studies Research Paper No. 2010, p. 442. Disponible en SSRN: http://ssrn.com/abstract $=1588283$

SCHIFF, Benjamin. Building the International Criminal Court Statute. Cambridge: University Press, 2008, p. 85. 
STAFFEN, Márcio Ricardo; CALLETI, Leandro (2017). Da necessidade de uma universalidade rediviva para os direitos humanos. Revista de Direito Brasileira, n. 16, n. 7, dez. 2017, p. 96-114.

TMI. United States et al v Hermann Wilhelm Göring. in Trial of the Major War Criminals before the International Military Tribunal. Vol 2. Nuremberg. 14 November 1945 - 1 October 1946 (1947) p. 99. Disponible en: https://www.loc. gov/rr/frd/Military_Law/pdf/NT_Vol-II.pdf

TMI. The Trial of German Major War Criminals: Before the International Military Tribunal. Vol. 1. Germany. 1947. Disponible en https://www.loc.gov/rr/frd/Military_Law/pdf/NT_Vol-I.pdf;

VAN DER VYVER, Johan. Prosecuting Terrorism in International Tribunals. Emory International Law Review. Vol. 24, N. 2, 2010, p. 535

VAN DER WILT, Harmen; BRABER, Inez. The case for inclusion of terrorism in the jurisdiction of the international criminal court. Amsterdam Law School Legal Studies, Research Paper N. 26, 2014. Available: https://papers.ssrn.com/sol3/papers. cfm?abstract_id $=24$

VAN SCHAACK, Beth. A Concise History of International Criminal Law. Santa Clara Univ. Legal Studies Research. Understanding International Criminal Law. Aspen Publishers. Paper No. 07-42. 2007, p. 22. Available at SSRN: http://ssrn. com/abstract=1016152:

ZACKLIN, Ralph. The Failings of Ad Hoc International Tribunals. Journal of International Criminal Justice. 2004, p. 541-545.

ZOLLER, Elizabeth. The Status of Individuals under International Law. in GINSBURGS, George; KURIADTSEV, V.N., The Nuremberg Trial and International Law. Dordrecht: Martinus Nijhoff Publishers, 1990, p. 101;

RECEBIDO EM: 14/05/2020

APROVADO EM: 20/07/2020

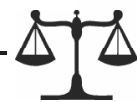

